\title{
DECOLORISATION OF BATIK WASTE WATER BY Marasmiellus palmivorus USING MODIFIED FIXED BED REACTOR
}

\author{
EDWAN KARDENA ${ }^{1 *}$, PRATAMA, A.N.K. ${ }^{2}$, SUHARDI, S.H. ${ }^{2}$, HASAN, K. ${ }^{3,4}$ and EFFENDI, A.J. ${ }^{1}$ \\ ${ }^{1}$ Department of Environmental Engineering, Institut Teknologi Bandung, Indonesia \\ ${ }^{2}$ School of Life Sciences and Technology, Institut Teknologi Bandung, Indonesia \\ ${ }^{3}$ Bioscience and Biotechnology Research Center, Institut Teknologi Bandung, Indonesia \\ ${ }^{4}$ Faculty of Medicine, Universitas Jendral Achmad Yani, Indonesia \\ ${ }^{*}$ E-mail: kardena@pusat.itb.ac.id
}

Accepted 30 April 2020, Published online 6 July 2020

\begin{abstract}
Batik waste water is dominated by textile dyes that are recalcitrant, hydrophobic, and molecular complexes. Azo, Nitroso, Azine, and Thiazolesare are among synthetic dyes used in batik industry. One of the well known white root fungus species that is able to degrade such dyes is Marasmiellus palmivorus. It has the ability to produce various enzymes such as manganese peroxidase, lignin peroxidase and laccase. Laccase (EC 1.10.3.2) catalyzes wide variety of aromatic hydrogen oxidation by reduction of oxygen and water. This research was conducted using two types of azo dye coloring agents, namely Levafix blue E-RA gran and Telon Red. This study was performed using optimized age of Solid State Fermentation (SSF), which was then inserted into a modified fixed bed reactor for 4 hours. Reduction of the color was observed every 15 minutes and the substrate used for growth of fungus was sawdust. The experiments demonstrated that crude enzyme of MarasmiellusSSF had activity of $97.8 \mathrm{U} / \mathrm{L}$ using ABTS reagent at 22-day of age bag log incubation. The total protein content, which was measured using the Bradford reagent, peaked at $154 \mathrm{mg} / \mathrm{L}$ on the 10th day. Such results indicated the great potential of utilizing Marasmiellus-SSF in modified fixed bad reactor to treat batik waste water.
\end{abstract}

Key words: Marasmiellus palmivorus, laccase, batik waste water, dye

\section{INTRODUCTION}

Wastewater from the textile industry is difficult to decontaminate, due to the fact that they are resistant to environmental degradation (Boehmer et al., 2006). Wastewaters contain dyes, which do not bind completely to the fabric and could vary from $2 \%$ for basic dyes to as high as $50 \%$ for reactive dyes (Pandey et al., 2007). Filamentous fungi are able to resist unfavorable conditions in biodegradation of dyes, in which microbes cannot survive. When discharged into aquatic systems, various reactions occur with dyes that lead to the formation of new xenobiotic compounds, which may be less or more toxic than the parental dye compounds (Kalpana et al., 2012). White-rot fungus is well known as most efficient microorganism in breaking down synthetic dyes. This property is due to this fungi's capacity to produce one or more extracellular ligninmodifying enzymes. These enzymes are also capable

* To whom correspondence should be addressed. of degrading a wide range of xenobiotics because they lack in substrate specificity (Wesenberg et al., 2007). Laccase has had the most important role in the initiation of the degradation process (Deacon et al., 2006). The enzyme could oxidize variety of aromatic hydrogen donors with reduction of oxygen to water. Furthermore, after laccase oxidizes phenolic and methoxyphenolic acids, it is able to decarboxylate them and attack their methoxy groups (demethylation) (Gianfreda et al., 1999; Rodrı'guez et al., 1999). However, enzymes when compared with conventional chemical catalysts have drawbacks such as high cost of their isolation and purification, their non-reusability, the instability of their structures and their sensitivity to process conditions. Fortunately, many of these undesirable limitations may be reduced by the use of immobilized enzymes (Taylor, 1991). Immobilization can be done by fixing microorganism on solid media, such as agricultural waste, which is relatively inexpensive and abundant, contains nutrients such as hemicellulose, cellulose 
and lignin and act as inducers to stimulate an enzyme production (Couto et al., 2005). By imitating the original occurrence in living cells, where enzymes are generally attached to the cell membrane, this system will stabilize the structure of the enzyme and its activity. In the immobilized form enzymes are more robust and more resistant to environmental changes allowing easy recovery and multiple reuse (Krajewska, 2004).

\section{MATERIALS AND METHODS}

\section{Fungi and lignocelluloses}

White rot fungi $M$. palmivorus used in this experiment was isolated by I Nyoman P. Aryantha and was maintained in Mycology Laboratory, Department of Bioscience and Biotechnology Research Center, Institut Teknologi Bandung, Indonesia. M. palmivorus was maintained on Potato Dextrose Agar (PDA) in the Petri dish. Wood sawdust was utilized to immobilize the fungi, urea of $1,5 \% \mathrm{w} / \mathrm{w}$, limestone $2 \% \mathrm{w} / \mathrm{w}$, and $5 \% \mathrm{w} / \mathrm{w}$ of rice bran were used as additional nutrients. Wood sawdust, which had been covered entirely by the fungus were then used as starter culture.

\section{Textile dyes}

In sequence to simulate the chemical conditions of textile wastewaters in the decolorisation experiments, concentrated solutions of two textile dyes, Levafix Blue E-RA Gran and Telon Red were prepared as follows. Portions of the dyes $(400 \mathrm{mg})$ and Na2SO4 (40 g) were added to $200 \mathrm{~mL}$ of water, the $\mathrm{pH}$ was adjusted to 12.5 and the compounds were dissolved by incubating the mixtures in a water bath at $80^{\circ} \mathrm{C}$ for $50 \mathrm{~min}$. They were then cooled to $22^{\circ} \mathrm{C}$ before they were used in the experiments (Boehmer et al., 2006). The concentrations used in this experiment were 100 ppm for Levaflix Blue E-RA Gran and 70 ppm for Telon Red.

\section{Optimization of incubation time}

In order to determine the best incubation time to produce the highest laccase activity, optimization had been carried out for 28 days by inoculating $270 \mathrm{~g}$ of sterilized wood sawdust with $30 \mathrm{~g}$ starter culture in plastic bag/bag log. $20 \mathrm{~g}$ was taken from bag $\log$ every 2 days, then extracted with phosphate buffer and reacted with ABTS. Sampling method used was the cone and quarter technique (Simmons, 1990) and each bag log was sampled only once.

\section{Biodecolorisation analysis}

The bag log already optimized was used in modified fixed bed reactor (Figure 1 and Figure 2). Peristaltic pump was used to lift the dyes with intake capacity of $31 \mathrm{~mL} / 100$ seconds. In every 15 minutes within 4 hours, sample was obtained. In control experiments, the effect of adsorption of the textile dyes on the substrate material was estimated by exposing wood sawdust to Levafix Blue E-RA Gran and Telon Red under the same conditions described above, but in the absence of fungi, over the same period.

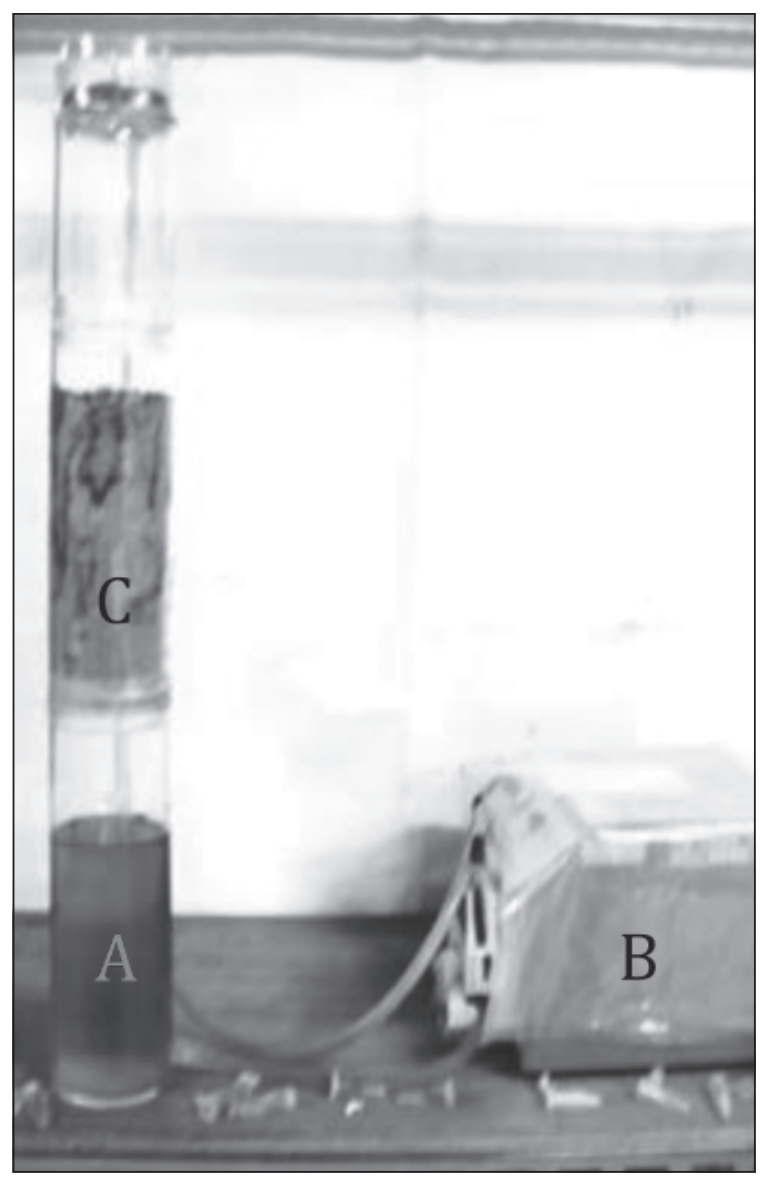

Fig. 1. (A) Modified fixed bed reactor, $1 \mathrm{~L}$ dyes waste water; (B) peristaltic pump; (C) $300 \mathrm{~g} \mathrm{SSF}$.

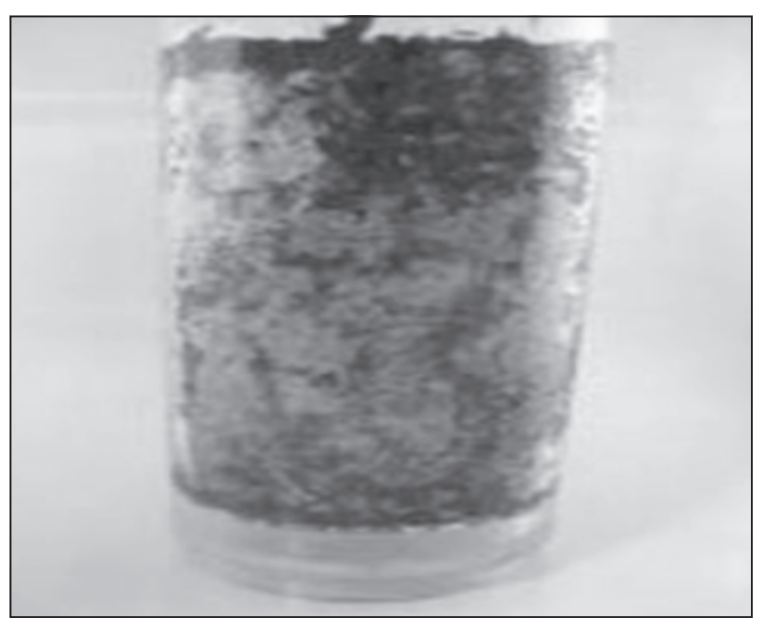

Fig. 2. Close up of SSF compartment. The reddish color due to adsorption of dye, and the white one is mycelium. 


\section{Enzyme and protein assays}

To study the effect of incubation time on laccase production, the experiments was carried out within 28 days, which every two days being checked for laccase activity and protein concentrations. Enzyme activities were estimated spectrophotometrically by using the crude supernatant fractions. The enzyme activity of laccase was determined by oxidation of 2,20- azinobis (3-ethylbenzthiazoline)-6-sulfonate (ABTS). Activity test was done by mixing $500 \mu \mathrm{L}$ of crude enzyme with $500 \mu \mathrm{L}$ of $0.5 \mathrm{mM}$ ABTS. ABTS oxidation was measured by looking at the increase in absorbance at $420 \mathrm{~nm}$ and laccase activity coefficient calculated from a decrease in molar $(\varepsilon)$ of $36,000 \mathrm{M}-1 \mathrm{~cm}-1$. One unit activity of the enzymes laccase showed the oxidation of $1 \mathrm{~mol}$ ABTS $\mathrm{ml} / \mathrm{min}$. The protein concentration was measured by using standard procedure of Bradford protein assay.

\section{UV-Vis spectral analysis}

The supernatants of control and experimental samples were evaluated for decolorisation by UVVis spectral analysis. Spectrum analysis was carried out using a Biorad UV-Vis spectrophotometer between the wavelength $300-700 \mathrm{~nm}$. The maximum wavelength for Levaflix Blue E-RA Gran was 615 $\mathrm{nm}$ and $530 \mathrm{~nm}$ for Telon Red

\section{RESULTS AND DISCUSSION}

\section{Optimization of incubation time}

Based on the results of incubation time optimization, laccase from Marasmiellus-SSF medium had activity at $97.8 \mathrm{U} / \mathrm{L}$ using ABTS reagent at 22-day of age bag log incubation. The total protein content, which was measured using the Bradford reagent, peaked at $154 \mathrm{mg} / \mathrm{L}$ on the 10 th day. The results obtained are presented in Figure 3. Laccase activity as seen from day 1-12 did not demonstrate significant increase. It was assumed using morphological observation on day 1-10 that fungal mycelium did not fully cover the bag log. It was still the preparatory phased of the mycelium/ biomass. The fungal mycelia in bag log were fully achieved by day 12 . When entering day 12 up to 22 , the growth of mycelia was enough and enzymatic activity increased sharply. However, when entering the day 22-28, laccase activity decreased due to less substrate/lignin remaining in medium as shown in Figure 3.

\section{Biodecolorisation analysis}

In the treatment of SSF, observed Levaflix Blue, which has a maximum wavelength at $615 \mathrm{~nm}$, had gradual decline until the blue color almost disappeared. Simultaneously, a new yellowish color also formed slowly in the wavelength at 380-420 $\mathrm{nm}$. The increase in absorbance below $380 \mathrm{~nm}$ also occurred but could not be observed visually since it was in the area of UV's wavelengths. In control experiments (without fungi), the effect of adsorption of the textile dyes on the substrate material was clearly different from SSF's result. In the wavelength of 380-420 $\mathrm{nm}$, there was sudden increased absorbance, indicating a new color appearing very quickly. On the other hand, the changed color at the $615 \mathrm{~nm}$ was slightly different from the SSF's result. Control experiment showed lower decolorisation rate than Solid State Fermentation.

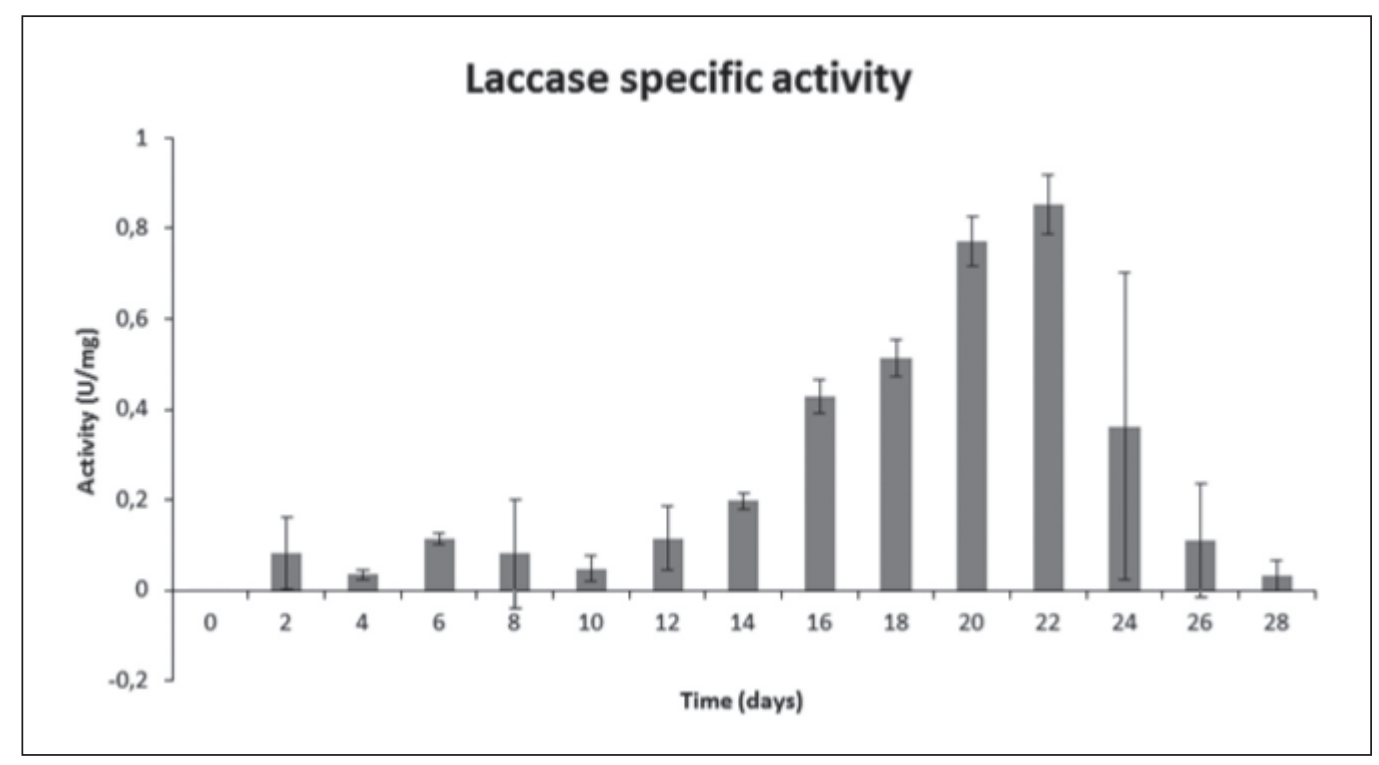

Fig. 3. Profile of laccase activity from M. Palmivorus. 
Telon Red has also undergone decolorisation gradually by using SSF. This was by the decrease of absorbance at its maximum wavelength $(530 \mathrm{~nm})$ and simultaneously, yellowish color slowly formed at wavelength $380-420 \mathrm{~nm}$. Moreover, in the control experiment, decolorisation process only occurred through the absorption and decolorisation rate was lower than the SSF at wavelength $530 \mathrm{~nm}$. The profile was similar to that shown in the decolorisation of Levaflix Blue (Figure 4 and Figure 5).

In comparison, differences of absorbance values between the control and SSF at wavelength 380-420 occurred significantly. On SSF, the formation of yellowish color occured slowly, while in the control was observed rapidly. It was due to the utilization of moisture content of the wood sawdust for biomass growth and $\mathrm{CO} 2$. Since the moisture content was lower than the control, the yellowish color of the wood heaps became fewer leached with the dyes. The formation of a new color (yellowish) confirmed with baseline experiment, operating the reactor with $1 \mathrm{~L}$ distilled water containing $300 \mathrm{~g}$ sterilized wood sawdust (Figure 6). Based on the graph, it could be explained about the sudden change in the trend of wavelength $380-420$. This phenomenon was attributed to the increasing of lignin concentration in the wastewater as a result of biomass degradation during fungi growth period (Hambali et al., 2010). Considering the experiment using natural biomass as media to grow and immobilize the fungi, there was also significant role of dye particles adsorption onto the medium surface during the treatment process. It was necessary to distinguish the role of each process and could be seen by comparing the

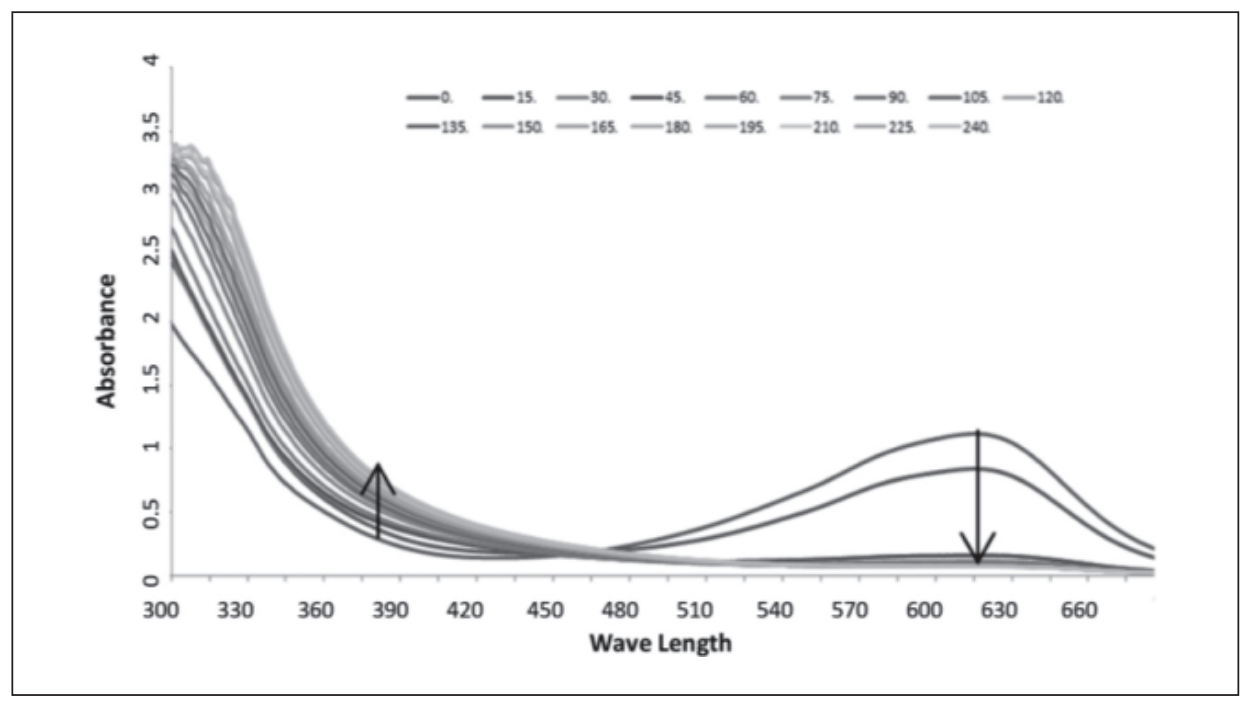

Fig. 4. Scanning wavelength from 300-700 nm for decolorisation Levaflix Blue E-R Gran with Marasmiellus palmivorus/SSF.

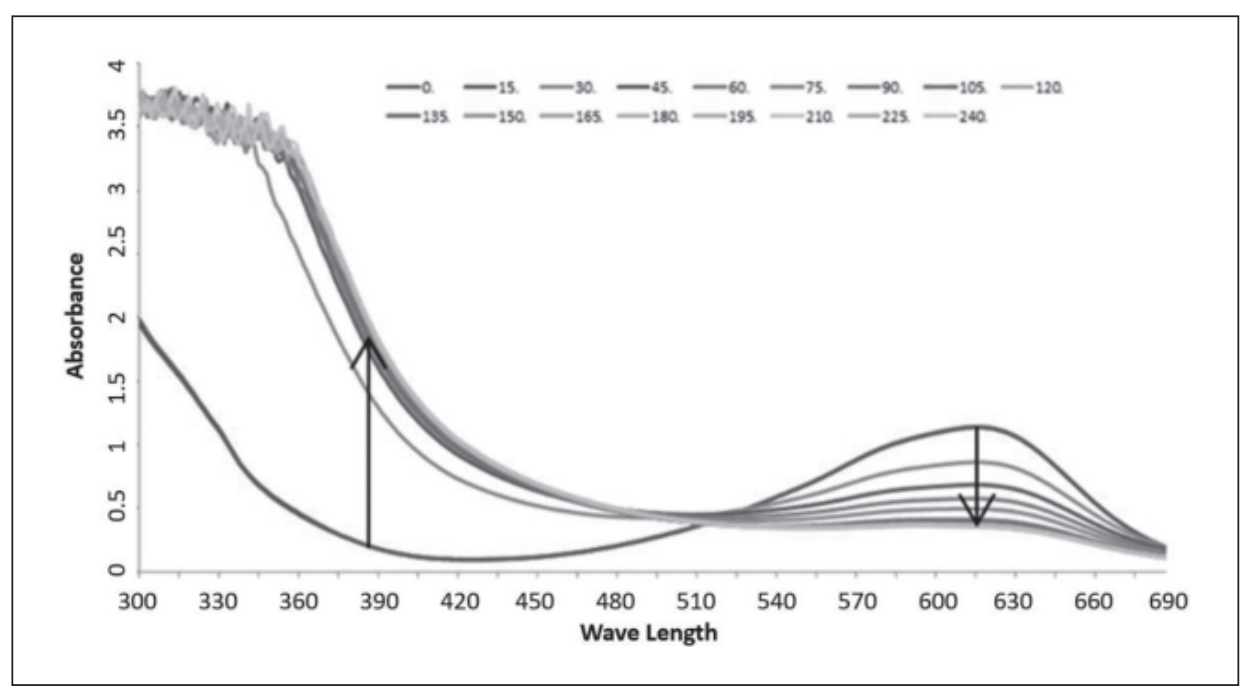

Fig. 5. Scanning wavelength from 300-700 nm for decolorisation Levaflix Blue E-R Gran by adsorption of control experiment. 


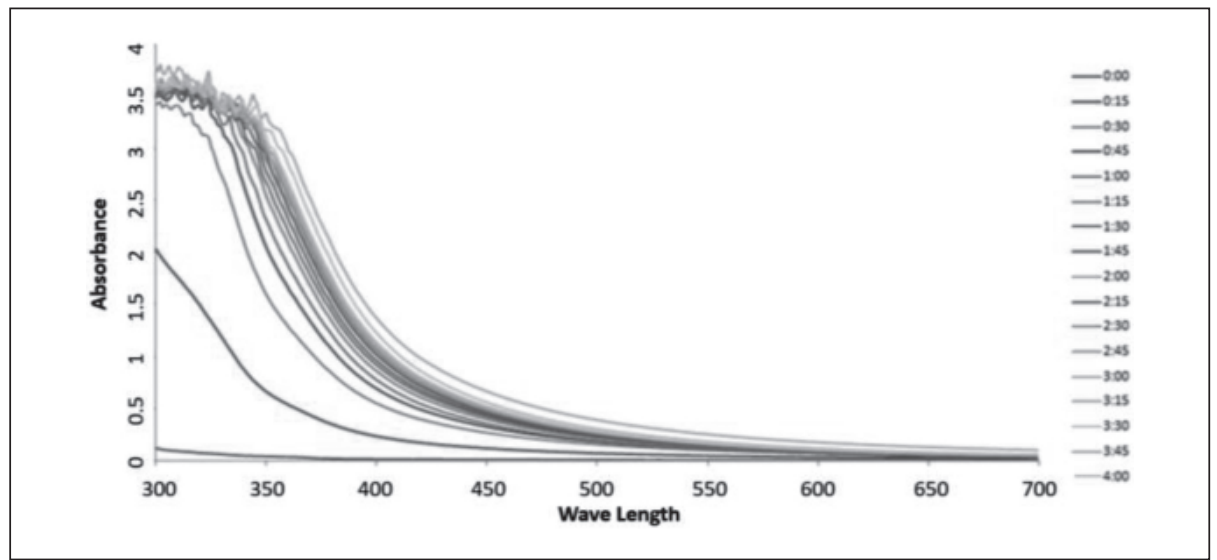

Fig. 6. Baseline experiment result, operating reactor with $1 \mathrm{~L}$ distilled water and sterilized wood sawdust.

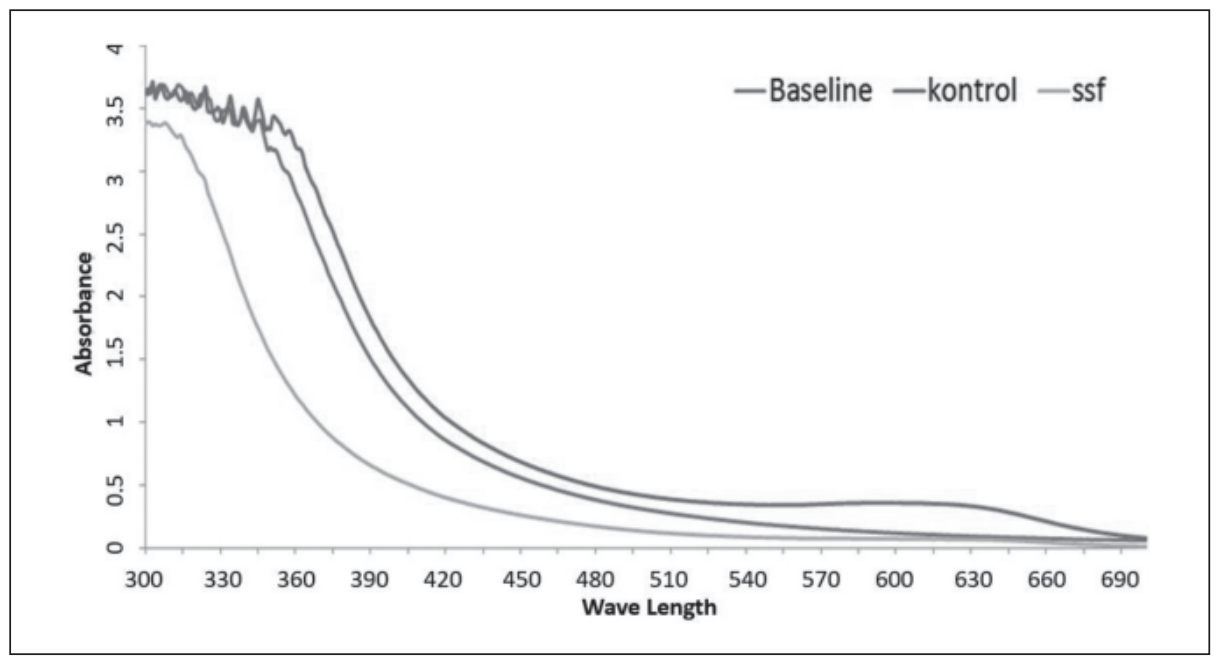

Fig. 7. Comparison of final result decolorisation Levaflix Blue E-RA Gran.

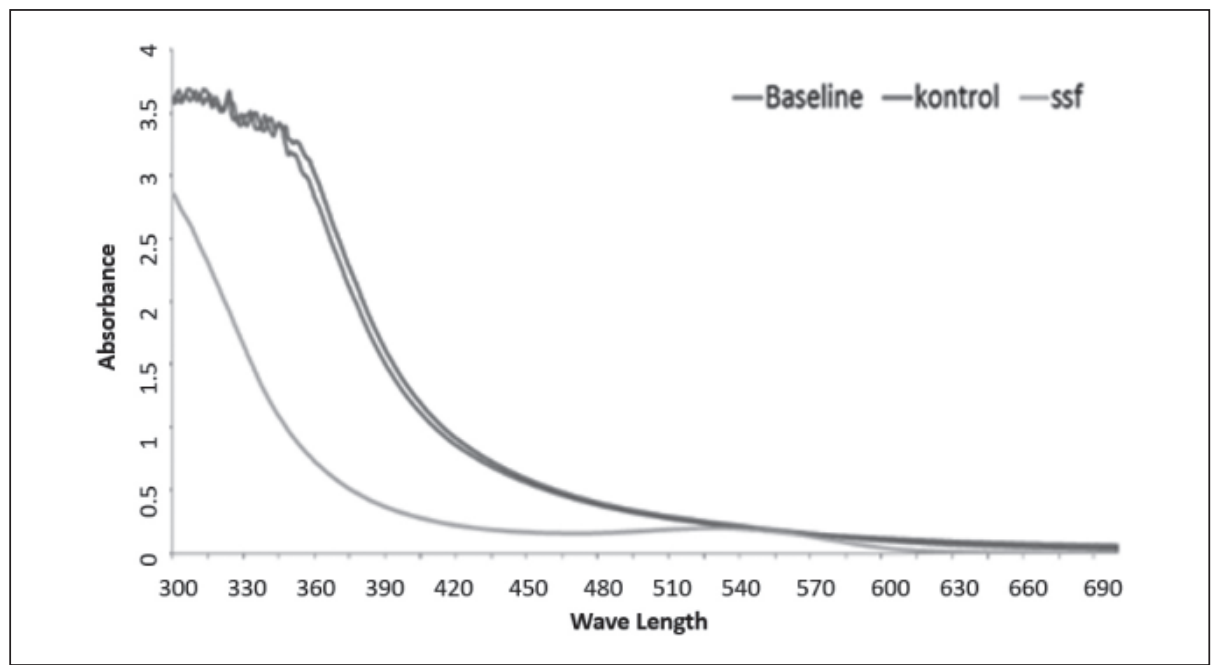

Fig. 8. Comparison of final result decolorisation Telon Red.

final results (after 4 hour process). Based on Figure 7 and Figure 8, it was clear that the process of adsorption had a dominant role in the decolorisation of dyes. However, enzymatic processes also play a role in the process of refining decolorisation because their colors faded better with the presence of fungi/ SSF. Furthermore, visual characterization on the fungi beds utilized for the treatment after few days 


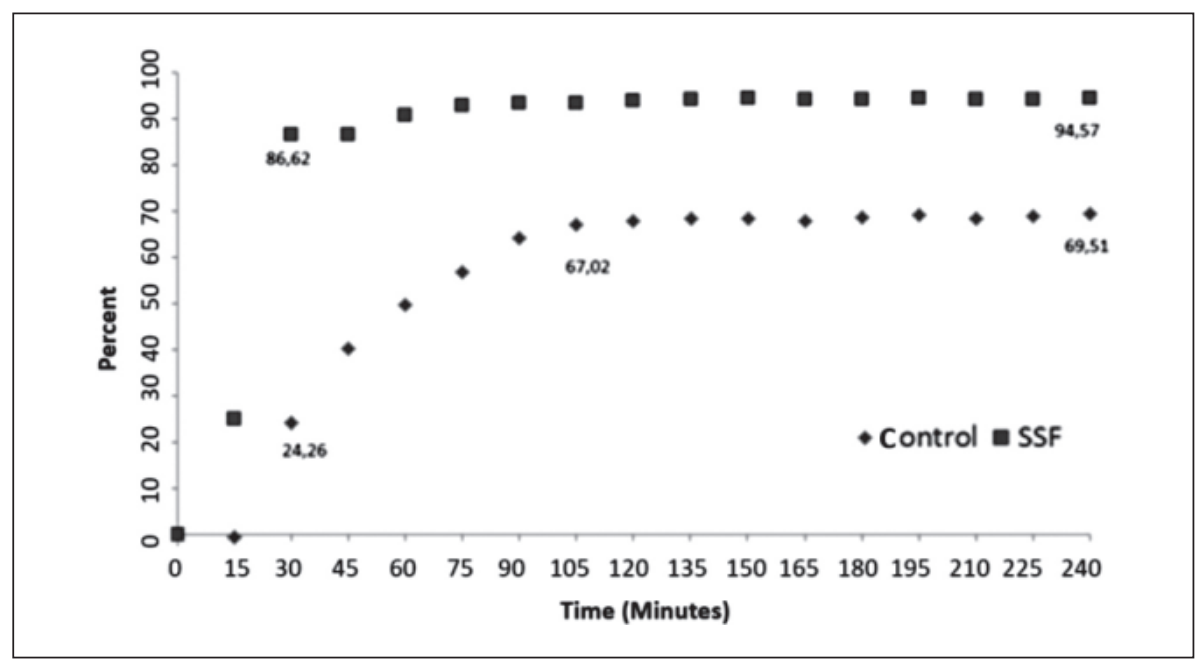

Fig. 9. Comparison between control and SSF for Percent Decolorisation of Levaflix Blue E-RA Gran.

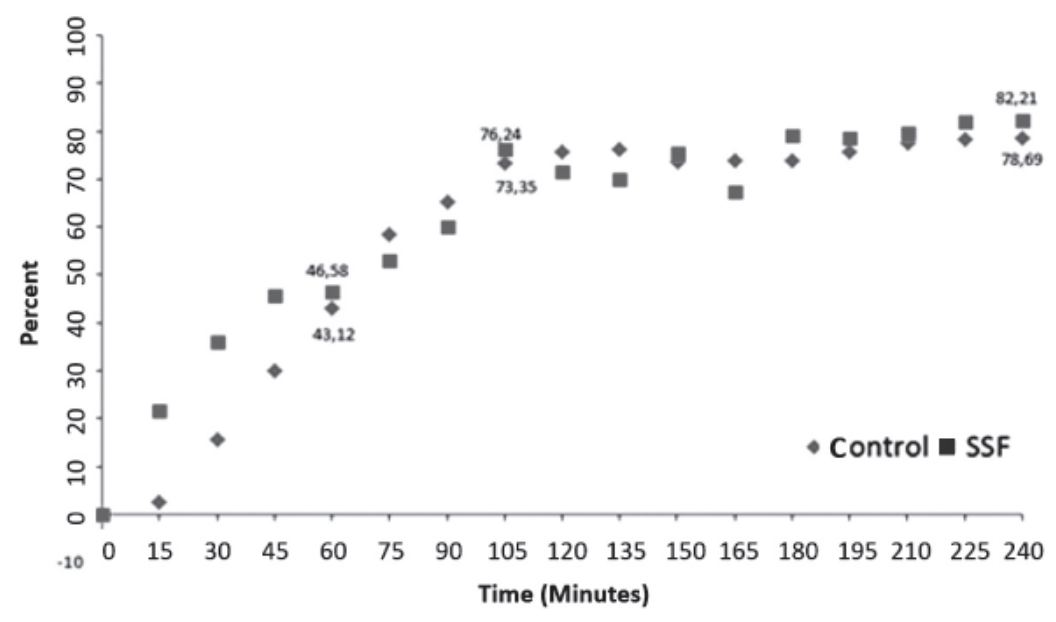

Fig. 10. Comparison between control and SSF for Percent Decolorisation of Telon Red.

showed that there was actual degradation of dye, catalyzed by enzyme produced by white-rot fungi. Red color of palm oil fiber faded away from day-today and eventually disappeared from the wood sawdust bed.

\section{Percent of decolorisation}

The immobilized enzyme showed lower stability than its free form in dyeing effluents. The stability of the enzyme depended on the dyeing liquor composition and the chemical structure of the dye. Adsorption appears to be the most important factor in decolorisation. However, both immobilized and free laccase showed a good decolorisation degree and re-dyeing in the enzymatically recycled effluent provided consistency of the color (Zille, 2005). The constant changed of decolorisation was generally achieved in 90th minute. Percent decolorisation of Levafliz Blue E-RA Gran reached
$79.35 \%$ in the SSF while only $64.49 \%$ observed in the control. The enzymatic action contributed to the $14.85 \%$ decolorisation of the process. Percent decolorisation of Telon Red reached $68.93 \%$ by $\mathrm{SSF}$, whereas in the control showed $61.71 \%$. Decolorisation due enzymatic activity in this case only amounted to $7.21 \%$. Degradation of various synthetic dyes by Marasmiellus palmivorus was also reported by Cantele et al. (2017). High percent decolorisation (10-95\%) was achieved in crude broth. A similar fungi namely Marasmius sp. was also reported to decolorise synthetic dye in a shaking culture (Vantamuri \& Kaliwal, 2017).

It was confirmed by this study that treatment with Marasmiellus palmivorus (WRF) could decolorise AZO based dyes such as Levaflix Blue E-RA Gran and Telon Red, respectively by adsorption and laccase activity (Figure 9 and Figure 10). Adsorption appears to be greater factor 
in decolorisation. Moreover, 70\% decolorisation could be obtained by using immobilized enzyme in less the 90 minutes. As reported by Anastasi et al. (2010), the application of fungi in the real reactor is still difficult due to the limitation of their ability to grow. Study on fungal treatment used in a reactor is still lacking. Thus the result from this study also contributes to the possibility of fungal application in a wastewater treatment to degrade textile effluent.

\section{ACKNOWLEDGMENTS}

The authors wish to thank Biosciences and Biotechnology Research Center-Institute of Technology Bandung and Ministry of Research, Technology and Higher Education Indonesia.

\section{REFFERENCES}

Anastasi, A., Spina, F., Prigione, V., Tigini, V., Giansanti, P. \& Varese, G.C. 2010. Scale-up of a bioprocess for textile wastewater treatment using Bjerkandera adusta. Biores Technol, 101: 3067-3075.

Boehmer, U., Suhardi, S.H. \& Bley, T. 2006. Decolorizing Reactive Textile Dyes with White-Rot Fungi by Temporary Immersion Cultivation. Engineering in Life Science No. 4.

Cantele, C., Vilasboa, J., Echer dos Reis, E., Claudete Fontana, R., Camassola, M. \& Dillon, A.J.P. 2017. Synthetic dye decolorisation by Marasmiellus palmivorus: Simultaneous cultivation and high laccase-crude broth treatment. Biocatalysis and Agricultural Biotechnology, 12: 314-322.

Couto, S.R. \& Sanromán, M.A. 2005. Application of Solid-State Fermentation Ligninolytic Enzyme Production. Biochemical Engineering Journal, 22: 211-219.

Deacon, J. 2006. Fungal Biology. Blackwell Publishing. Oxford. 231-233.
Gianfreda, L., Xu, F. \& Bollag, J-M. 1999. Laccases: a useful group of Oxidoreductive enzymes. Bioremediation Journal, 3: 1-26.

Hambali, H.C., Suwito, E., Suhardi, S.H. \& Setiadi, T. 2010. Textile Wastewater Decolorisation Performance using Marasmius sp. in Immersion and Trickling Systems. Department of Chemical Engineering, Faculty of Industrial Technology, Institut Teknologi Bandung.

Kalpana, D., Velmurugan, N., Shim, J.H., Oh, B.T., Senthil, K. \& Lee, Y.S. 2012. Biodecolorisation and biodegradation of reactive Levafix Blue ERA granulate dye by the white rot fungus Irpex lacteus. Journal of Environmental Management, 111: $142-149$.

Krajewska, B. 2004. Application of chitin- and chitosan-based materials for enzyme immobilizations: a review. Enzyme and Microbial Technology, 35: 126-139.

Pandey, A., Singh, P. \& Iyengar, L. 2007. Bacterial decolorisation and degradation of azo dyes. International. Biodeteriotion Biodegradation, 59: 73-84.

Rodr1'guez, E., Pickard, M.A. \& Vazquez-Duhalt, R. 1999. Industrial dye decolorisation by laccases from ligninolytic fungi. Current Microbiology, 38: 27-32.

Simmons, M.S. 1990. Hazardous wastes measurements. Lewis publisher Inc. Michigan. 58-59.

Taylor, R.F. 1991. Protein immobilization: Fundamental and applications. Marcel Dekker Inc., New York, USA.

Vantamuri, A.B. \& Kaliwal, B.B. (2017). Decolourization and biodegradation of Navy blue HER (Reactive Blue 171) dye from Marasmius sp. BBKAV79. 3 Biotech: 7(1): 48.

Wesenberg, D., Kyriakides, I. \& Agathos, S.N. 2003. White-rot fungi and their enzymes for the treatment of industrial dye effluents. Biotechnology Advances, 22: 161-187.

Zille, A. 2005. Laccase Reactions for Textile Applications. Universidade do Minho Escol de Engenharia, 4. 
